\title{
Pragmatic and Fragile Effects of Wastewater on a Soil- Plant-Air Continuum and Its Remediation Measures: A Perspective
}

\author{
Aqarab Husnain Gondal ${ }^{1 *}$, Koko Tampubolon ${ }^{2 *}$, Muhammad Danish Toor ${ }^{3}$ and Mujahid Ali ${ }^{1}$ \\ ${ }^{1}$ Institute of Soil and Environmental Sciences, University of Agriculture, 38040, Faisalabad, Punjab, Pakistan \\ 2 Program Study of Agrotechnology, Faculty of Agriculture and Animal Husbandry, Universitas Tjut Nyak Dhien, \\ Medan 20123, Sumatera Utara, Indonesia \\ ${ }^{3}$ European University of Lefke, Institute of Graduate Studies and Research, Department of Environmental \\ Sciences Northern Cyprus TR-10 Mersin, Turkey
}

\begin{abstract}
Water is an essential input for agricultural development and irrigated agriculture. However, groundwater reliance is rising due to lack of canal water and is often inferior quality, costly, scarce, and ultimately expensive for smallholders. Moreover, as hunger rises daily due to population growth, additional irrigation water systems are needed to extend the cropping patterns. Therefore, wastewater (WW) use in agriculture has been increased on a growing scale over the last decades due to its fertilizing capacity and decrease in canal water and freshwater availability. It enhances soil productivity by contributing organic matter contents and preserves water and nutrients for plants. Various traditional treatments such as primary, secondary, and tertiary treatments are being used, but more working is required due to health and environmental issues. Therefore, the end product of tertiary treatments could be mixed with different water sources (for dilution), phytoremediator plants in channels and use of microbes that eat waste food could be adopted because the maximum crop yield is primarily determined by water quality, as well as climatic conditions, water management practices, chemical and physical soil properties. Besides, we can minimize the all-potential risks associated with agricultural activities and production via strengthened strategies, systemic dialogues, and financial frameworks. The present review discusses WW irrigation are that it provides a safer water source to the farmers and has the beneficial elements of providing essential plant nutrients after treatment and environmental sustainability.
\end{abstract}

\section{Keywords}

microbes, phytoremediation, plant growth, wastewater, water deficiency

\section{Introduction}

Plants and any living organism cannot survive without water because about 80 to $90 \%$ of most plant cells are required a sufficient amount of water. The plant stem, fruits, leaves contain 70 to $80 \%$ water, and it plays a crucial role in photosynthesis, biochemical processes, photochemical processes, transpiration, and metabolism of plants [13]. Without water application, plants are unable to uptake the nutrients, and ultimately, growth is reduced. Hence, plants require an adequate amount of water to develop plants' proper growth and development [4]. The rivers, streams, lakes are the natural source of water for all life forms present in the universe, and without sufficient water, everything is just like a deadly disaster. Globally, the proportion of domestic and industrial wastewater flows that 
are safely treated according to national or local standards for its intended recipients (lakes, rivers, ocean, or soil) or further uses (agriculture) by $56 \%$ in 2020 [5].

In the case study from Pakistan, formerly a country with surplus water sources, is now a country with a water shortage. Pakistan has an extensive canal system and other water sources, but water supply has declined from 1,299 $\mathrm{m}^{3}$ per capita in 1996-1997 to $1,100 \mathrm{~m}^{3}$ per capita in 2006, with less than $700 \mathrm{~m}^{3}$ per capita expected by 2025 [6]. Currently, 40.5 Million Acre Feet (MAF) of freshwater is drained daily, $60-80 \%$ classified as saline, and about $36 \%$ of the groundwater categorized as extremely saline [7]. By 2025, the water supply is expected to be less than $700 \mathrm{~m}^{3}$ per capita compared to the world water of $1500 \mathrm{~m}^{3}$ per capita [8]. According to recent statistics, the Indus Basin River System (IBRS) and its tributaries storage capacity is about 142 MAF of water per year on an average basis, nearly 36 MAF flows to the sea, 96 MAF is used for drainage, and about 10 MAF is absorbed by system losses, including evaporation, seepage, and spill during floods [6,9]. This system (IBRS) irrigates $90 \%$ of food crops and $100 \%$ of Pakistan agriculture's cash crops [10]. Approximately 21.2 million hectares of land are cultivated by Pakistan farmers, of which more than $80 \%$ grow water-intensive crops (e.g. sugarcane, maize, rice and wheat etc.) that are used more than $93 \%$ of Pakistan water that is greater than global used $(73 \%)[11,12]$.

Pakistan's water resources are reducing due to various inadequate strategies and improper management practices [12]. The increasing population requires more fresh water and food for their survival (drinking and other purposes), contributing to water scarcity, and increased wastewater (WW) supply. A considerable volume of water is required for food production; for instance, $5 \mathrm{~m}^{3}$ water is utilized to manufacture one person's food daily in Europe $[13,14]$. In less-developed nations, such as Pakistan, food losses are much higher [15], potentially leading to depleting many freshwaters. Therefore, a rise in demand for water and food has contributed more WW towards agriculture usage and reduced freshwater use [16]. Alternative water sources (WW) are the need for the current and coming situation. The use of WW for irrigation may also be an acceptable solution and is highly supported [17].

An estimation has shown that enormous amounts of WW are produced in several Pakistan central districts [18]. According to a conservative estimate, Pakistan WW is specifically used to irrigate an area of 32,500 ha [19]. The average volume of direct WW used in agriculture is projected to be $0.876 \times 10^{9} \mathrm{~m}^{3} / \mathrm{yr}$, with $0.146 \times 10^{9} \mathrm{~m}^{3} / \mathrm{yr}$ being directly disposed of to water sources [20]. It has various beneficial effects as well, such as (a) WW disposal during the whole year, (b) shortage of water can be solved, (c) higher quality sources can be used for potable uses (d) economically beneficial [21]. Due to large production and positive effects, it is of considerable importance. The fundamental purposes of WW irrigation are that it provides a safer water source to the farmers and has the beneficial elements of providing essential plant nutrients after treatment and environmental sustainability.

\section{Review result}

\subsection{Wastewater effects on soil fertility and plant growth}

In developed and developing countries, the use of WW for irrigation is essential because of its higher nutritional status, mainly because it contains nitrogen $(\mathrm{N})$ and phosphorus $(\mathrm{P})$, which enhances the quality of soil fertility [22]. According to Angelakis et al. [23], the use of sewage sludge in the soil increases organic matter production, soil nutrients, crop yield, decreases the number of inorganic fertilizers, and has an adequate amount of heavy metals. The WW is a potential source of macronutrients, especially potassium $(\mathrm{K})$ and micronutrients such as boron (B), magnesium $(\mathrm{Mg}$ ), calcium $(\mathrm{Ca})$, zinc $(\mathrm{Zn})$, iron $(\mathrm{Fe})$ and manganese $(\mathrm{Mn})[24,25]$ and is source-dependent. The WW nutrient contents affect soil fertility and chemical properties, soil buffering ability, and cation exchange reactions [17]. It provides many naturally occurring nutrients that minimize fertilizers' expenses [26,27,28], thus protecting the environment directly and the water bodies indirectly through the return of macro and micronutrients by rains. It 
also affects the $\mathrm{pH}$ of the soil which is most important factor of soil fertility determination [29]. Its supplementation to the soil is considered the nutritional source of phosphatic and nitrogenous fertilizer [30]. Its utilization to the crop plants surprisingly increases the physical, chemical, and biological properties, which led to stimulating the plant growth and development of wheat [31] and other crops. The WW also includes sodium $(\mathrm{Na})$, copper $(\mathrm{Cu}), \mathrm{Mn}$, and other trace elements, and the uptake of these elements is essential to obtain an optimum yield of crop plants [32].

For agricultural irrigation purposes, the treatment of WW decreases the volume of water that has to be collected from the source of freshwater [9]. The increases in WW for irrigation is seen as a technological option for reducing soil depletion and restoring soil nutrient content. WW usage has improved salinity and reduced $\mathrm{pH}$ [33]. Some positive trends have been observed, including an increase in organic matter, N, large cation concentrations, and heavy soil metals [34]. Therefore, it is also vital for vegetable production, as well. According to Smit and Nasr [35], one-tenth or more of the world's population eats foods grown with WW irrigation. According to Hussain et al. [36], untreated or partly treated WW is used to irrigate at least 20 million hectares in 50 countries. In India, WW irrigation is used to irrigate nearly 73,000 peri-urban farmland [37]. Farmers in peri-urban areas typically use year-round intensive vegetable production systems or other perishable commodities like fodder to gain up to four times more per unit land area production than freshwater farmers [38]. It is projected that sewage water irrigates about 1 million hectares [39] to 1.5 million hectares of land per year, contributing to one million tons of nutrients and 130 million person-days of work [38]. Its composition also includes several metals, toxic materials, gasses and oil, pathogens, solids, bases, acids, nutrients, inorganic toxin compounds, inorganic and organic material $[40,41,42]$ which may be harmful to various systems including soil-air-water and plant.

The tolerance of different plants to wastewater irrigation has been reported, Hajihashemi et al. [43] reported that the WW irrigation significantly decreased photosynthetic characteristics such as chlorophyll fluorescence, intercellular $\mathrm{CO}_{2}$, net photosynthesis, water use efficiency, and photosynthetic pigments in wheat plants and followed by the reduction in photosynthesis and the leaf thickness, root diameter, and reducing phloem, xylem, and cortical parenchyma cells of the origins and thickness of mesophyll. Chu et al. [44] stated that molecules containing P, ATP and NADP, are very important for utilizing the energy of photosynthetic to make arrangements for carbohydrates. Likewise, the reduction of $\mathrm{P}$ in leaves in wastewater irrigation can reduce carbohydrate content and consequently inhibit soybean growth. The researchers also stated that the decrease in carbohydrates as a plant response to wastewater was associated with nutritional imbalances and impaired photosynthesis. Oyiga et al. [45] added that the inhibition of leaf area could be due to the accumulation of $\mathrm{Na}^{+}$in the leaves of wheat plants from WW irrigation, resulting in reduced carbohydrate supply to young leaves. One of WW's immediate impacts is the enhanced reactive oxygen species (ROS), which abolishes the cell membrane components and nucleic acids and leads to sustained oxidative stress caused by heavy metals [43,46,47]. The ROS-induced lipid membrane (peroxidation) is known as a reflection of cellular stress-induced damage. The higher level of heavy metals disrupts the mitochondrial electron transport chain, which controls the plants breathing [48]. ROS can cause damage to biomolecules such as lipids, proteins and DNA, damaging the cell integrity and ultimately leading to its death [49].

\subsection{Issues of wastewater related to Soil-Wter-Air-Plant System}

The WW application has some negative impacts on soil-air-water and plant continuum [50]. These are all linked together; if one is affected, the other is ultimately affected directly or indirectly. For instance, the standing of WW in water bodies pollutes the environment by releasing heavy metals. They come back to the soil through the rain; it indirectly affects soil fertility and the food chain through plants, as shown in Figure 1. 


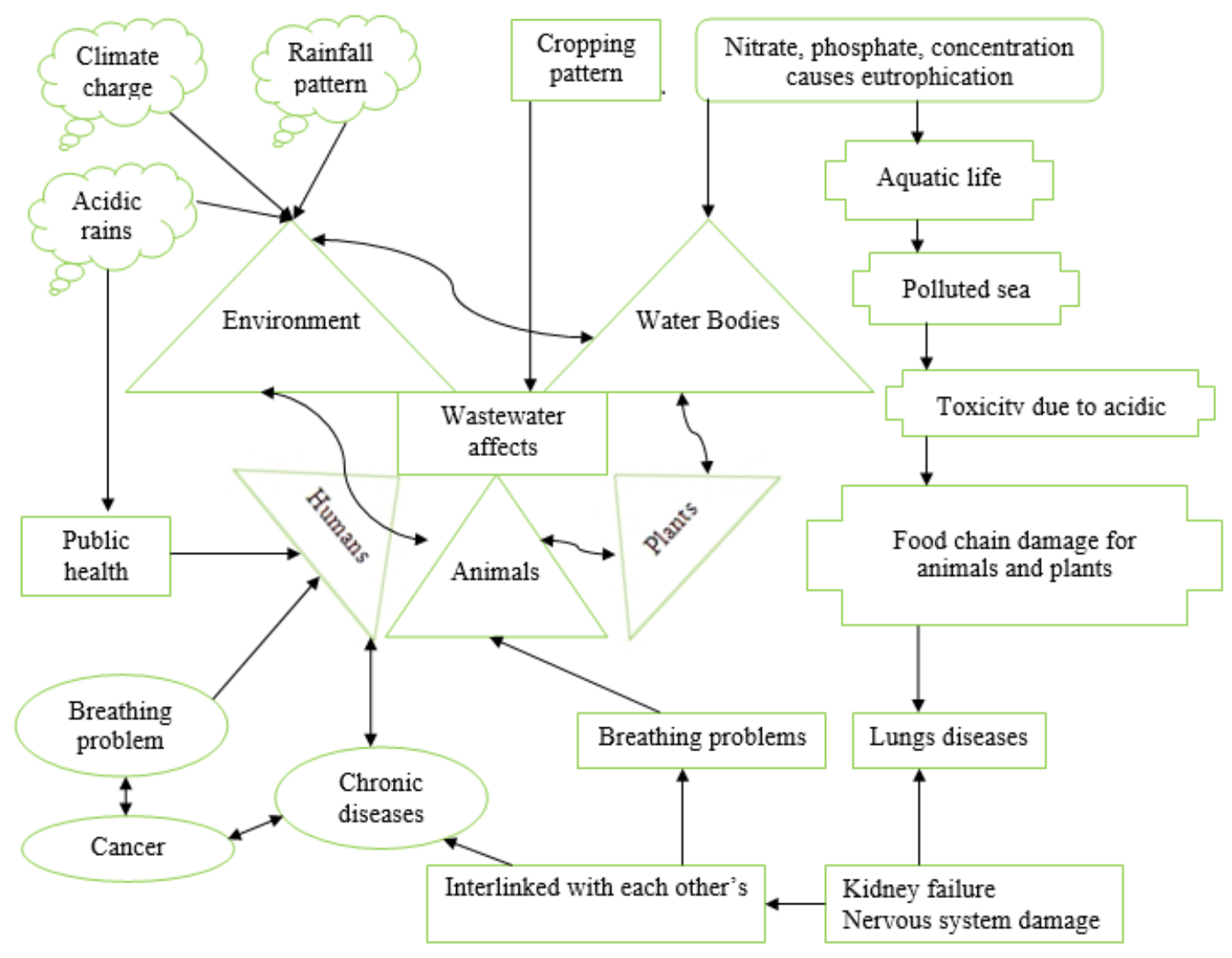

Figure 1: The direct and indirect effects of WW on soil-plant-air, and humans-animal systems

According to Edokpayi et al. [51], WW has negative consequences on the ecosystem almost from all aspects. The WW treatment can also create mud, which is also detrimental to health because it is a polluted substance that needs safe handling and removal [52]. It is capable of being corrosive, poisonous, ignitable, reactive, and acidic. Hence, human beings are also affected depending on WW types. Therefore, they have many direct and indirect consequences on all these systems.

\subsection{Air and water}

The immediate impacts of WW on the landscape are degradation and destruction of natural ecosystems and species living in them by exposing them to chemical pollutants that are not typically present in nature $[53,54,55]$. The oceans, transpiration, submission, and evaporation from liquid phases maintain the atmosphere's moisture contents. More than $90 \%$ moisture is misplaced towards the environment through evaporation (USGS Science for the Changing World). The standing of WW at any place lead to polluting the soil and environment through evaporation when temperature rises [56]. The previous finding explains that heavy metals' very minute concentration in the air disturbs the whole aerobic community [57]. For instance, humans and plants breath in the air and causes different diseases when metals concentration becomes toxic [58]. Microbial air pollution is another problem related to WW treatment that causes typhoid fever, cholera, diarrhoea, chronic exposure, mental disorder, liver and kidney failure, and various other diseases [58,59]. Microorganisms survive optimally in the presence of air [60] and act as bio-aerosols, transported from various ecosystems (water, soil, water, animals, surface plants, and others) and 
through sneezing, wind gusts, and coughing. The WW disposal during water purification is also a cause of bioaerosols [61]. It is processed before being used for irrigation in developing countries with strict environmental regulations. Therefore, in some under developing countries where treatment cost is beyond the people level, the WW is directly used for agricultural purposes [36].

In some ways, every ecosystem relies on water. Almost all habitats are placed at significant risk when hazardous substances, garbage, and other synthetic pollutants [62] contaminate water. The water we cannot use goes out because all of the WW collected by our cities each day from factories, households, and industries, inevitably returns to the ecosystem to be used again. When WW is treated insufficiently, the world's water supply is suffered due to climatic factors etc. The WW water also pollutes the freshwater bodies through acidic rains, which affect the aquatic life [63]. Notwithstanding that the planet's atmosphere consists entirely of water bodies [64], remember that we pour garbage into individual water bodies and means we are polluting the water we might use again. However, this does not reflect the full scope of wastewater's environmental impacts.

\subsection{Remediation measures}

In certain parts of the world, urban WW utilization in agriculture is a common occurrence. Rough figures suggest that untreated or partly treated WW irrigates at least 20 million hectares in 50 countries [22]. Since small communities are more likely to be personally responsible for their WW, they must understand its characteristics (components, length, strength, and flow) and how specific factors influence their lives. Hence, the recycling of WW becomes necessary [65]. It is not a matter of dramatic improvement, but instead of a slow and steady reversal of poor habits and improving acceptable practices. For people, livestock, and the world as a whole, this pollution faces various dangers. Therefore, before being reused or redirected into the water source, it must undergo therapy. Multiple strategies are being used to overcome the WW problem, are shown in Figure 2.

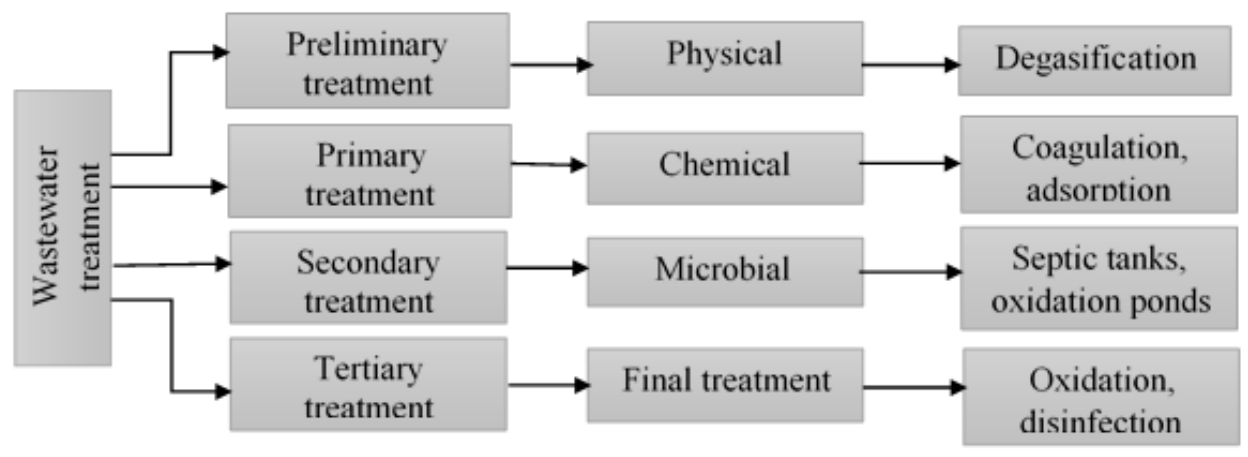

Figure 2: Various methods of WW treatments are currently being used

\subsubsection{Primary, secondary, and tertiary treatment}

Many solids are present in WW before they were arriving at the treatment facility. The food fragments, eggshells, rags, paper, wood, plastic, and even money and toys fall into this group [66]. For the proper treatment of WW, three tanks of huge storage quantities could be used when WW reaches the first tank, where it goes through comprehensive screening filters that eliminate the solids. The solids are then disposed of in a dumpster at a landfill and are the only non-recyclable byproduct of WW treatment. After that, the WW would flow from the first tank to two massive circular tanks in which it speeds down and stays for almost two hours, causing material suspended in the WW to either rise to the surface or fall to the bottom. 
The WW flows from the first tank to vast, quadrilateral tanks. It undergoes a natural therapy in which artificial air is applied for microbes that eat the food wastes and convert them into less toxic products. The WW in this tank is mixed with the active sludge and the number of actively disappearing single-celled microbes such as bacteria and fungi (primarily inherent microorganisms and plants). The water seems to be boiling when there is so much air applied. These microbes need air to survive and reproduce. This process should be completed in almost 8 hours. Materials in the drainage, drain, float and revolving arms separate this material from the secondary tank. After that, water seems as clean as drinking water in the tertiary tank, and it can enter the purification structure. The addition of polymers allows the solid spheres to come together, making it easier to filter them.

\subsubsection{Other treatments}

After that, treated water should undergo the following remaining processes. The WW therapy at the point source is vital. For instance, urban WW could be directly used for agricultural irrigation purpose while industrial source requires treatment before use, as shown in Figure 3.

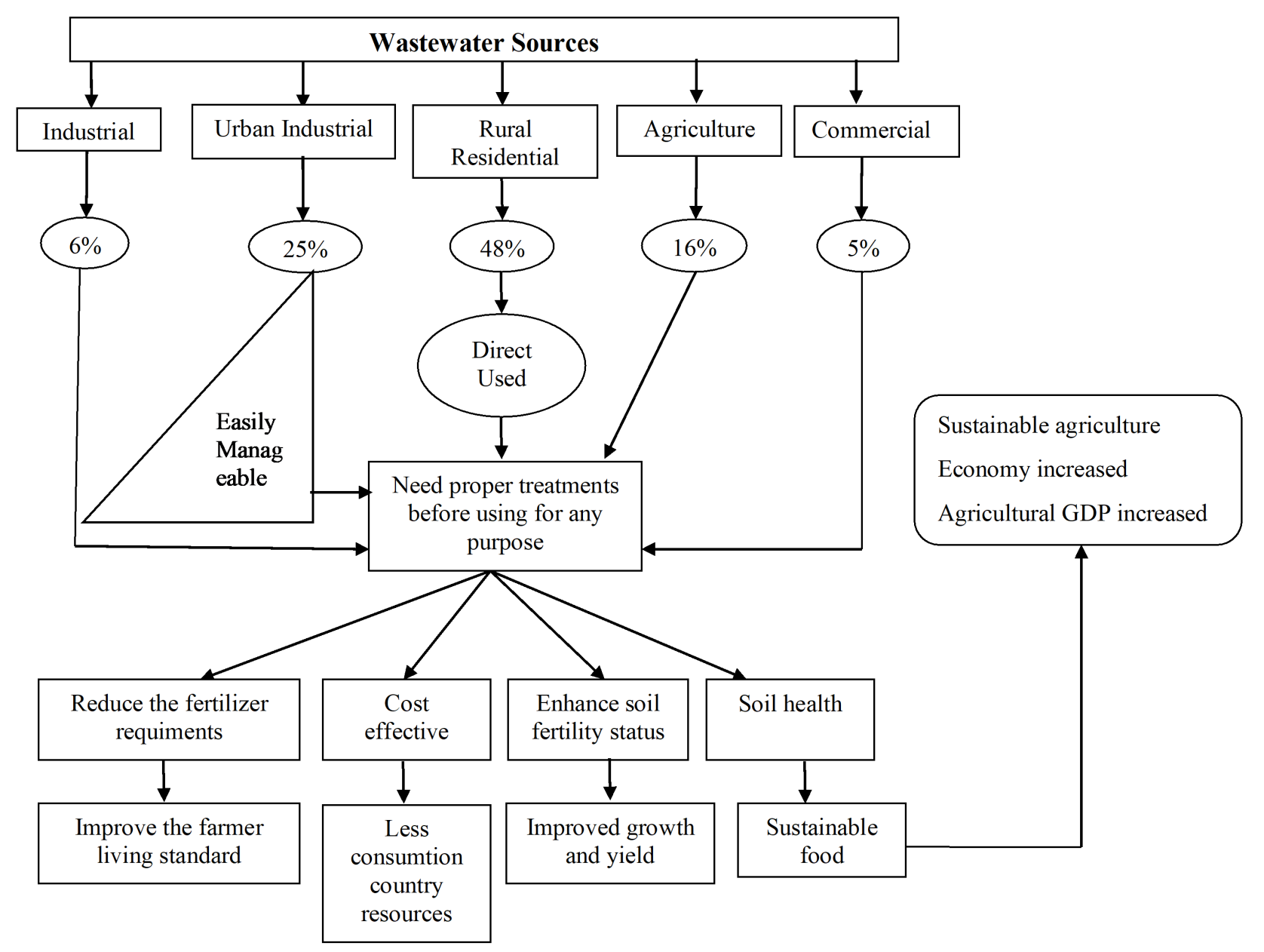

Figure 3: Sources of WW and their therapies 


\subsubsection{Mixing}

Various studies showed that mixing WW with freshwater or canal water significantly improves the soil's nutritional status and plant growth. The 1:1,1:2, and or 1:3 WW combining with other water sources, respectively, can be beneficial from all aspects of life. Therefore, the treated water (an end product of tertiary treatments) should be mixed with fresh water before its use for any purpose. According to Rajor et al. [65], dilution of WW with fresh water for rabi and Kharif crops could be beneficial for growth and yield improvement. Industrial WW dilution also improves cotton and sorghum crops growth [67].

\subsubsection{Microbial approach}

Many microbes are present in WW, either harmful or beneficial for all kinds. Here the beneficial microbes that tolerate the heavy metals concentration up to the mark, and dangerous means the minimum ability of microbes towards heavy metal tolerance. The isolation of beneficial microbes and their further multiplication through genome replication can be a suitable option. It might be possible that the product of genome replication of microbes accepts the heavy metal challenge. The end product of genetic engineering should be applied in a third treated tank, and or its application could be suitable in the field where WW is used.

\subsubsection{Phytoremediation}

It has been seen that most plants tolerate the heavy metal concentration up to an extent. Growing these plants in the water channels from which WW passes could be a suitable option to mitigate the effects positively. Lu et al. [68] said that the plant metabolism can restore or cleanse the contaminated areas. The pollutants are absorbed by plants through the roots with a detoxification mechanism, provides surface area for adsorption and accumulation of water and nutrients that promote plant growth. These pollutants are absorbed and stored in the roots, can also be in the stems, or leaves; converted into less harmful chemicals in plants; or converted into gas which is released into the air as transpiration. Yeboah et al. [69] reported that the phytoremediation using vetiver grass (Vetiveria zizanioides) can improve wastewater quality and reduce/eliminate negative effects on the environment during wastewater discharge. Sulastri \& Tampubolon [70] also reported that vetiver grasses were also can absorb heavy metal cadmium with a higher uptake ratio in the roots (15.47) than in the shoots (2.00). It was indicated that the heavy metal cadmium is higher absorbed in the roots of vetiver grasses.

\section{Conclusions}

Existence on earth began with water and is dependent on water, which is essential for the survival of all living things. For instance, water is a crucial constituent of the plant as well as for animals and humans. Water has emerged as the most significant and widespread limiting factor in influence the plant growth and development. Plants receive and excrete water regularly, which has various biochemical and physiological roles in plant organisms. In terms of water requirement, plant species and individual plant parts vary. The world water resources are reducing due to various problems. Groundwater reclaimed from aquifers recharged with low-quality water has been used for anything from landscape irrigation to potable water. The value of using such waters for different purposes is determined by the quantity, nature, and expense of alternate sources of supplies, which varies greatly depending on location and sources. Advanced treatment process flow schemes and other engineering controls provide a solid foundation for improving water reuse applications. Due to the advancement of technology and a better understanding of health and environmental risks, the feasibility of producing reclaimed water of a specific quality to meet multiple water use objectives is now a reality. However, the ultimate decision to extract recycled WW is based on regulatory, 
fiscal, and public policy considerations representing the need for a reliable water source and water pollution control in megacities. The use of recycled WW would provide ample stability to enable a water agency to meet short-term needs while still the water source efficiency, as addressed in this segment, by integrated water reuse planning. Accurate cost statistics are becoming more critical as the preparation and construction of drainage reclamation and reuse infrastructure becomes more critical.

\section{REFERENCES}

[1] Ouyang Y (2002) Phytoremediation: modeling plant uptake and contaminant transport in the soil-plant-atmosphere continuum. Journal of Hydrology, 266(1-2): 66-82. https://doi.org/10.1016/S0022-1694(02)00116-6.

[2] Busch S (2019) Percentage of water in fruits and vegetables. Available at: https://www.livestrong.com/article/350652percentage-of-water-in-fruits-vegetables/.

[3] Zhao W, Liu L, Shen Q, Yang J, Han X, Tian F and Wu J (2020) Effects of water stress on photosynthesis, yield, and water use efficiency in winter wheat. Water, 12(8): 2127. https://doi.org/10.3390/w12082127.

[4] George E (2000) Nutrient uptake. In Arbuscular mycorrhizas: physiology and function. Springer, Dordrecht, pp.307-343.

[5] UN-Water (2021) Indicator 6.3.1-Wastewater treatment. Available at: https://www.sdg6data.org/indicator/6.3.1.

[6] Murtaza G and Zia MH(2012) Wastewater production, treatment and use in Pakistan. In Second regional workshop of the project 'safe use of wastewater in agriculture, pp. 16-18.

[7] Ministry of Economic Affairs and Statistics (2011) Overall water availability. Ministry of economic affairs and statistics, Statistics division. Government of Pakistan. Available at: http://www.pbs.gov.pk/sites/default/files/other/yearbook2011/AGRICULTURE/1-15.pdf

[8] Pak-SCEA (2006) Pakistan; strategic country environmental assessment. Report. Available at: http://climateinfo.pk/frontend/web/attachments/data-type/pakceavolume1.pdf.

[9] Muzammil M. Zahid A and Breuer L (2020) Water resources management strategies for irrigated agriculture in the Indus Basin of Pakistan. Water, 12(5): 1429. https://doi.org/10.3390/w12051429.

[10] Ringler C and Anwar A (2013) Water for food security: challenges for Pakistan. Water International, 38(5), 505-514. https://doi.org/10.1080/02508060.2013.832122.

[11] Chandio J (2014) Crisis of federalism in Pakistan: Issues and challenges. Federalism in Asia and beyond The Wildbad Kreuth Federalism Days 2012. 119p.

[12] Sleet P (2019) Water resources in Pakistan: scarce, polluted and poorly governed. Independent Strategic Analysis of Australia's Global Interest. Nedlands.

[13] World Water Assessment Programme (2017) The United Nations world water development report 2017. Wastewater: the untapped resource. Paris, UNESCO. Available at: https://unesdoc.unesco.org/ark:/48223/pf0000247153.

[14] Cortese RDM, Veiros MB, Feldman C and Cavalli SB(2016) Food safety and hygiene practices of vendors during the chain of street food production in Florianopolis, Brazil: A cross-sectional study. Food Control, 62: 178-186. https://doi.org/10.1016/j.foodcont.2015.10.027.

[15] Khalid S, Naseer A, Shahid M, Shah GM, Ullah MI, Waqar A, Abbas T, Imran M and Rehman F (2019) Assessment of nutritional loss with food waste and factors governing this waste at household level in Pakistan. Journal of Cleaner Production, 206: 1015-1024. https://doi.org/10.1016/j.jclepro.2018.09.138.

[16] Mhaske AR and Nikam PJ (2017) Impact of treated domestic sewage irrigation on crop yield, plant uptake and soil properties in Central India. In Proceedings of the International Conference on Science \& Engineering for Sustainable Development, pp.7992.

[17] Mohammad MJ and Mazahreh N (2003) Changes in soil fertility parameters in response to irrigation of forage crops with secondary treated wastewater. Communications in Soil Science and Plant Analysis, 34(9-10): 1281-1294. https://doi.org/10.1081/CSS-120020444.

[18] Ministry of Water and Power (2002) Pakistan water sector strategy. National water sector profile, volume 5. Ministry of Water and Power, Office of the Chief Engineering Advisor. Available at: http://waterinfo.net.pk/cms/pdf/vol5.pdf. 
[19] Ensink JH, Mahmood T, Van der Hoek W, Raschid-Sally L and Amerasinghe FP (2004) A nationwide assessment of wastewater use in Pakistan: an obscure activity or a vitally important one?. Water Policy, 6(3): 197-206.

https://doi.org/10.2166/wp.2004.0013.

[20] WB-CWRAS (2005) Pakistan-country water resources assistance strategy: water economy running dry. World Bank. Available at: http://documents.worldbank.org/curated/en/315851468285362706/Pakistan-Country-water-resources-assistance-strategywater-economy-running-dry.

[21] Oron G, Goemans M, Manor Y and Feyen J (1995) Poliovirus distribution in the soil-plant system under reuse of secondary wastewater. Water Research, 29(4): 1069-1078. https://doi.org/10.1016/0043-1354(94)00257-8.

[22] Jiménez B (2006) Irrigation in developing countries using wastewater. International Review for Environmental Strategies, 6(2): 229-250.

[23] Angelakis AN, Do Monte MM, Bontoux L and Asano T (1999) The status of wastewater reuse practice in the Mediterranean basin: need for guidelines. Water Research, 33(10): 2201-2217. https://doi.org/10.1016/S0043-1354(98)00465-5.

[24] Barreto AN, Do Nascimento JJ, Medeiros EPD, Nóbrega JAD and Bezerra JR (2013) Changes in chemical attributes of a Fluvent cultivated with castor bean and irrigated with wastewater. Revista Brasileira de Engenharia Agrícola e Ambiental, 17(5): 480-486. https://doi.org/10.1590/S1415-43662013000500003.

[25] Tarantino E, Disciglio G, Gatta G, Libutti A, Frabboni L, Gagliardi A and Tarantino A (2017) Agro-industrial treated wastewater reuse for crop irrigation: implication in soil fertility. Chemical Engineering Transactions, 58: 679-684.

[26] Drechsel P, Scott CA, Raschid-Sally L, Redwood M and Bahri A (2010) Wastewater irrigation and health: assessing and mitigating risk in low-income countries. International Water Management Institute, London, UK.

[27] Winpenny J, Heinz I, Koo-Oshima S, Salgot M, Collado J, Hérnandez F and Torricelli R (2013) Reutilización del agua en agricultura: beneficios para todos. FAO: Rome, Italy, 124.

[28] Toze S (2006) Reuse of effluent water—benefits and risks. Agricultural Water Management, 80(1-3): 147-159. https://doi.org/10.1016/j.agwat.2005.07.010.

[29] Gondal AH, Hussain I, Ijaz AB, Zafar A, Ch BI, Zafar H, Sohail MD, Niazi H, Touseef M, Khan AA, Tariq M, Yousuf H and Usama M (2021) Influence of soil pH and microbes on mineral solubility and plant nutrition: a review. International Journal of Agriculture and Biological Sciences, 5(1): 71-81.

[30] Metcalf L, Eddy HP and Tchobanoglous G (1991) Wastewater engineering: treatment, disposal, and reuse. New York: McGraw-Hill.

[31] Khan N (2018) Natural ecological remediation and reuse of sewage water in agriculture and its effects on plant health. In: Sewage (Zhu IX, ed.), IntechOpen Publisher. https://doi.org/10.5772/intechopen.75455.

[32] Linden DR, Clapp CE and Dowdoy RH (1983) Hydrologic management: nutrients. In Proceedings of the workshop on utilization of municipal wastewater and sludge on land. Riverside, University of California. pp.79-103.

[33] Abd-Elwahed MS (2018). Influence of long-term wastewater irrigation on soil quality and its spatial distribution. Annals of Agricultural Sciences, 63(2): 191-199. https://doi.org/10.1016/j.aoas.2018.11.004.

[34] Angin I, Yaganoglu AV and Turan M (2005) Effects of long-term wastewater irrigation on soil properties. Journal of Sustainable Agriculture, 26(3): 31-42. https://doi.org/10.1300/J064v26n03_05.

[35] Smit J and Nasr J (1992) Urban agriculture for sustainable cities: using wastes and idle land and water bodies as resources. Environment and Urbanization, 4(2): 141-152. https://doi.org/10.1177\%2F095624789200400214.

[36] Hussain I, Raschid L, Hanjra MA, Marikar F and van der Hoek W (2001) A framework for analyzing socioeconomic, health and environmental impacts of wastewater use in agriculture in developing countries. International Water Management Institute, Sri Lanka.

[37] Strauss M and Blumenthal UJ (1990) Human waste use in agriculture and aquaculture. Utilization, practices and health perspectives, executive summary. International Reference Center for Waste Disposal, Duebendorf, Switzerland.

[38] Minhas PS and Samra JS (2004) Wastewater use in peri-urban agriculture: impacts and opportunities. In: Wastewater use in peri-urban agriculture: impacts and opportunities. Central Sol Salinity Research Institute, India.

[39] World Health Organization (2006) WHO guidelines for the safe use of wasterwater excreta and greywater. World Health Organization, Switzerland.

[40] Cisneros BJ (2011). Safe sanitation in low economic development areas. Treatise on Water Science, 4: 147-200. https://doi.org/10.1016/B978-0-444-53199-5.00082-8. 
[41] Yaqoob AA, Parveen T, Umar K and Mohamad Ibrahim MN (2020) Role of nanomaterials in the treatment of wastewater: a review. Water, 12(2): 495. https://doi.org/10.3390/w12020495.

[42] Wuana RA and Okieimen FE (2011) Heavy metals in contaminated soils: a review of sources, chemistry, risks and best available strategies for remediation. International Scholarly Research Notices, 2011, 20p. https://doi.org/10.5402/2011/402647.

[43] Hajihashemi S, Mbarki S, Skalicky M, Noedoost F, Raeisi M and Brestic M (2020) Effect of wastewater irrigation on photosynthesis, growth, and anatomical features of two wheat cultivars (Triticum aestivum L.). Water, 12(2): 607. https://doi.org/10.3390/w12020607.

[44] Chu S, Li H, Zhang X, Yu K, Chao M, Han S and Zhang D (2018) Physiological and proteomics analyses reveal lowphosphorus stress affected the regulation of photosynthesis in soybean. International Journal of Molecular Sciences, 19(6): 1688. https://doi.org/10.3390/ijms19061688.

[45] Oyiga BC, Sharma RC, Shen J, Baum M, Ogbonnaya FC, Léon J and Ballvora A (2016) Identification and characterization of salt tolerance of wheat germplasm using a multivariable screening approach. Journal of Agronomy and Crop Science, 202(6): 472-485. https://doi.org/10.1111/jac.12178.

[46] Liu N and Sun G (2011) Production of reactive oxygen species by photoactive anthraquinone compounds and their applications in wastewater treatment. Industrial \& Engineering Chemistry Research, 50(9): 5326-5333. https://doi.org/10.1021/ie101423v.

[47] Li L, Li J, Bai J, Zeng Q, Xia L, Zhang Y, Chen S, Xu Q and Zhou B (2019) The effect and mechanism of organic pollutants oxidation and chemical energy conversion for neutral wastewater via strengthening reactive oxygen species. Science of the Total Environment, 651(1): 1226-1235. https://doi.org/10.1016/j.scitotenv.2018.09.302.

[48] Dai Y, Wang Z, Zhao J, Xu L, Xu L, Yu X, Wei Y and Xing B (2018) Interaction of CuO nanoparticles with plant cells: internalization, oxidative stress, electron transport chain disruption, and toxicogenomic responses. Environmental Science: Nano, 5(10): 2269-2281. https://doi.org/10.1039/C8EN00222C.

[49] Das K and Roychoudhury A (2014) Reactive oxygen species (ROS) and response of antioxidants as ROS-scavengers during environmental stress in plants. Frontiers in Environmental Science, 2, 53. https://doi.org/10.3389/fenvs.2014.00053.

[50] Durán-Álvarez JC and Jiménez-Cisneros B (2014) Beneficial and negative impacts on soil by the reuse of treated/untreated municipal wastewater for agricultural irrigation-a review of the current knowledge and future perspectives. In: Environmental Risk Assessment of Soil Contamination (Maria C and Hernandez-Soriano, ed.), IntechOpen Publisher, Croatia, pp.137-197.

[51] Edokpayi JN, Odiyo JO and Olasoji SO (2014) Assessment of heavy metal contamination of Dzindi river, in Limpopo Province, South Africa. International Journal of Natural Science Research, 2(10): 185-194.

[52] Gupta VK, Ali I, Saleh TA, Nayak A and Agarwal S (2012) Chemical treatment technologies for waste-water recycling-an overview. RSC Advances, 2(16): 6380-6388. https://doi.org/10.1039/C2RA20340E.

[53] Environmental Protection Agency (2000) National water quality inventory: 1998 report to congress. Environmental Protection Agency, United States.

[54] Environmental Protection Agency (2012) Basic information about polychlorinated biphenyls (PCBs) in drinking water. Environmental Protection Agency, United States.

[55] Edokpayi JN, Odiyo JO and Durowoju OS (2017) Impact of wastewater on surface water quality in developing countries: a case study of South Africa. In: Water Quality (Hlanganani Tutu, ed.), IntechOpen Publisher, Croatia, pp.401-416.

[56] Shuangchen M, Jin C, Gongda C, Weijing Y and Sijie Z (2016) Research on desulfurization wastewater evaporation: present and future perspectives. Renewable and Sustainable Energy Reviews, 58: 1143-1151. https://doi.org/10.1016/j.rser.2015.12.252.

[57] Ekpo KE, Asia IO, Amayo KO and Jegede DA (2008) Determination of lead, cadmium and mercury in surrounding water and organs of some species of fish from Ikpoba river in Benin city, Nigeria. International Journal of Physical Sciences, 3(11): 289292.

[58] Jaishankar M, Tseten T, Anbalagan N, Mathew BB and Beeregowda K N (2014) Toxicity, mechanism and health effects of some heavy metals. Interdisciplinary Toxicology, 7(2): 60-72. https://dx.doi.org/10.2478\%2Fintox-2014-0009.

[59] Akpor OB, Otohinoyi DA, Olaolu DT and Aderiye BI (2014). Pollutants in wastewater effluents: impacts and remediation processes. International Journal of Environmental Research and Earth Science, 3(3): 050-059.

[60] Postgate J (2000) Microbes and man. Cambridge University Press. https://doi.org/10.1017/CBO9780511612008.

[61] Douwes J, Thorne P, Pearce N and Heederik D (2003) Bioaerosol health effects and exposure assessment: progress and prospects. The Annals of Occupational Hygiene, 47(3): 187-200. https://doi.org/10.1093/annhyg/meg032. 
[62] Bloganica (2017) What are the effects of wastewater on the environment? Available at: https://www.organicawater.com/effectswastewater-environment/.

[63] Renou S, Thomas JS, Aoustin E and Pons MN (2008) Influence of impact assessment methods in wastewater treatment LCA. Journal of Cleaner Production, 16(10): 1098-1105. https://doi.org/10.1016/j.jclepro.2007.06.003.

[64] Elkins-Tanton LT and Seager S (2008) Ranges of atmospheric mass and composition of super-earth exoplanets. The Astrophysical Journal, 685(2): 1237.

[65] Rajor A, Kunal and Bhalla G (2016) Impact of sewage on seed germination and growth of kharif and rabi crops. Journal of Chemistry, Environmental Sciences and Its Applications, 3(1): 1-18. https://doi.org/10.15415/jce.2016.31001.

[66] Talvitie J, Mikola A, Koistinen A and Setälä O (2017) Solutions to microplastic pollution-Removal of microplastics from wastewater effluent with advanced wastewater treatment technologies. Water Research, 123: 401-407. https://doi.org/10.1016/j.watres.2017.07.005.

[67] Jothimani P and Bhaskaran A (2002) Effects of dilution and dynamics of physical factors during factory effluent irrigation. Journal of Ecotoxicology \& Environmental Monitoring, 12(4): 255-261.

[68] Lu H, Li Z, Fu S, Méndez A, Gascó G and Paz-Ferreiro J (2014) Can biochar and phytoextractors be jointly used for cadmium remediation?. PLoS One, 9(4), e95218. https://doi.org/10.1371/journal.pone.0095218.

[69] Yeboah SA, Allotey ANM and Biney E (2015) Purification of industrial wastewater with vetiver grasses (Vetiveria zizanioides): the case of food and beverages wastewater in Ghana. Asian Journal of Basic and Applied Science, 2(2): 1-14.

[70] Sulastri YS and Tampubolon K (2019) Aromatic plants: phytoremediation of cadmium heavy metal and the relationship to essential oil production. International Journal of Scientific and Technology Research, 8(8): 1064-1069. 